FOLIA SCANDINAVICA VOL. 25 POZNAŃ 2018 DOI: $10.2478 /$ fsp-2018-0012 sciendo

PRESSto.

\title{
THE IN-OUT SPATIAL RELATION AS CONCEPTUALIZED AND VERBALIZED BY DANISH DIRECTIONAL ADVERBS AND THEIR EQUIVALENTS IN POLISH
}

\author{
ALEKSANDER KACPRZAK \\ Adam Mickiewicz University in Poznań
}

ABSTRACT. The present paper aims to investigate and compare the conceptualization and verbalization of the in-out relation in Danish and Polish. The introductory paragraphs focus on the differences in the distribution of content in Polish and Danish employing Leonard Talmy's typological classification of languages into verb-framed and satelliteframed, and provide information about Danish Directional Adverbs which are believed to be the key to understanding spatial relations in Danish. The analysis in the following paragraph reveals similarities and differences in the perception of the in-out relation through image schemas such as CONTAINER and CENTER-PERIPHERY. The analysis of the CENTER-PERIPHERY image schema in Danish reveals that there is often a presupposed reference point in situations where the directional adverb does not refer to the in-out relation denoted by the prepositional phrase, which leads to a description of the general structure of this image schema in the last part of the article.

\section{INTRODUCTION}

Danish Directional Adverbs (DDAs) are a small group of words used to convey spatial relations in the Danish language. Three forms of Danish Directional Adverbs are distinguished, i.e. the dynamic $-\varnothing$ form, the static $-e$ form and the procedural $-a d$ form (Hovmark 2013) as in the following sentences: 
(1a) Han gik ind i butikken. ${ }^{1}$ 'He went inside the shop'

(2a) Han er inde i omklædningsrummet. 'He is in the locker room'

(3a) Han fulgte åen indad mod byen. 'He followed the river in the direction of the city'

There are no equivalent forms in the Polish language which is apparent in the Polish translations below:

(1b) Wszedł do sklepu 'He went inside the shop'

(2b) Jest w szatni. 'He is in the locker room'

(3b) Podążał za strumieniem w kierunku miasta. 'He followed the river in the direction of the city'

This leads us to the question: do we conceptualize spatial relations differently? The present paper is an attempt to answer the question and describe how the speakers of Danish and Polish conceptualize the in-out spatial relation, with a particular focus on DDAs and the means used in Polish to convey similar content. The next two sections establish a foundation for the analysis: the second section provides a short overview of the previous publications concerning DDAs and the third section describes the difference in distribution of content in Danish and Polish based on Leonard Talmy's classification of languages, with a particular focus on the role of DDAs as satellites. In section 4 the most common image schemas by which Polish and Danish speakers perceive the in-out relation are presented, along with an analysis of the differences in its verbalization in both languages. Danish Directional Adverbs constitute the reference point for the analysis and they are subsequently translated into Polish in order to provide a foundation for the comparative analysis. Section 5 provides a summary of the analysis carried out in sections 3 and 4 .

\section{PREVIOUS ANALYSES OF DDAs}

In many years Danish Directional Adverbs had not been subject for a sufficient semantic analysis given their uniqueness and the key role they play in conveying spatial relations in Danish language. One of the first complex analyses of DDAs was carried out in 1996 by Peter Harder, Lars Heltoft and Ole Nedergaard Thomsen (Harder et al. 1996) and focused primarily on their

${ }^{1}$ The examples in the article are the author's own and have been created in collaboration with native speakers of Danish and Polish. 
syntactic role within Danish complex predicates. The semantical difference between the three different types of DDA was described as corresponding to what is traditionally called aktionsart, and was based on the static/dynamic and transitional/non-transitional (or transformative/non-transformative) oppositions. Later, in 2003, Tavs Bjerre (Bjerre 2003) analyzed the connection between DDAs and locative prepositions in Danish. The semantical study of the DDA paradigm was also a part of Hansens and Heltofts grammar - Grammatik Over Det Danske Sprog - in 2011 (Hansen/Heltoft 2011:838-53), where the authors characterized DDAs as a means to express telicity and described their role within compound adjectives. Finally, a complex semantical study of the whole paradigm from a cognitive perspective was released in a Ph.D. dissertation and a series of articles by the Danish linguist Henrik Hovmark (Hovmark 2007, 2008, 2009, 2013). He described the contrast between the three types of DDAs by means of cognitive linguistics: the conceptualization of a path event frame constitutes the base and the three different types of DDAs profile this base in different ways. All the aforementioned publications have established a foundation for the present analysis and allowed me to comprehend the key role DDAs play in conveying the conceptualization of the in-out relation in Danish.

The comparative perspective has been taken in the article written by Michat Smułczyński (2016) that focuses on the way Danish adverb $u d$ is translated into Polish. Comparative studies have also been carried out for Swedish directional adverbs and their equivalents in Polish (Strzelecka 2003, 2014).

\section{DIFFERENCES IN DISTRIBUTION OF CONTENT IN POLISH IN DANISH. THE DDA PARADIGM.}

Every language gives its speakers a possibility to express spatial relations, but languages differ in ways in which they convey them. Henrik Hovmark, who relies on Leonard Talmy's division of languages into satellite-framed and verb-framed, categorizes DDAs as satellites that encode directionality (Hovmark 2013). The small paradigm of DDAs consists of the 10 adverbs presented in Fig. $1^{2}$.

As one may notice, there are three different forms of DDAs: a zero-form (ind-Ø), an $-e$ form (ind-e) and an -ad form (ind-ad). Henrik Hovmark describes the difference between the three forms as a difference in "profiling a dynamic goal-oriented motion from $\mathrm{p}$ to $\mathrm{q}$ in a path event frame" (Hovmark 2013). Peter Harder, Lars Heltoft and Ole Nedergaard Thomsen describe it as coding the contrast between three aktionsart: static/dynamic and transitional/ non-transitional (Harder et al. 1996). In Hansens and Heltofts grammar it is described as a contrast between static/dynamic and telic/non-telic forms.

\footnotetext{
${ }^{2}$ Presented in alphabetical order.
} 


\begin{tabular}{cccc}
\hline $\begin{array}{c}\text { Dynamic } \\
\text { DDA (-Ø) }\end{array}$ & $\begin{array}{c}\text { Static DDA (- } \\
\text { e) }\end{array}$ & $\begin{array}{c}\text { Procedural } \\
\text { DDA (-ad) }\end{array}$ & $\begin{array}{c}\text { English } \\
\text { Translation }\end{array}$ \\
\hline bort & borte & $-{ }^{3}$ & 'away' \\
\hline hjem & hjemme & hjemad & 'home' \\
\hline hen & henne & henad & $\begin{array}{c}\text { horisontal } \\
\text { direction }\end{array}$ \\
\hline ind & inde & indad & 'in' \\
\hline ned & nede & nedad & 'down' \\
\hline om & omme & (omad) $* 4$ & 'around' \\
\hline op & oppe & opad & 'up' \\
\hline over & ovre & - & 'over'/'across' \\
\hline tilbage & tilbage & - & 'ouck' \\
\hline ud & ude & udad & \\
\hline
\end{tabular}

(Fig. 1) The overview of Danish Directional Adverbs

In the present article I employ Henrik Hovmarks description of the semantics of the DDA paradigm in that it seems to establish the most optimal foundation for a profound analysis of the oppositions within the paradigm. Therefore I also follow Talmy's terminology as path, motion, motion event (Talmy 2000b:25), path event frame (Talmy 2000a:265), figure and ground (Talmy 2000b:25). I also use Ronald Langackers terms base and profile (Langacker 2005:21). The construction of a motion event frame is shown below:

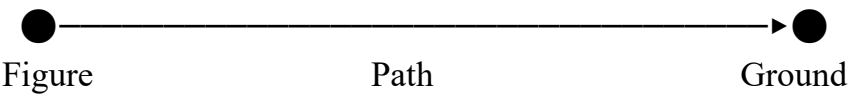

(Fig. 2) Motion event frame (Hovmark 2007:54)

As it was pointed out before, the three different forms of DDAs are specific ways of profiling the motion event frame. The dynamic form, as shown in the figure below, is used to profile the whole frame, which means a "change of position or state from $\mathrm{p}$ to $\mathrm{q}$ along a path of motion" (Hovmark 2013).

\footnotetext{
${ }^{3}$ This symbol represents a form does not occur in the corpus.

${ }^{4}$ This symbol indicates a form that occurs in the corpus only occasionally.
} 


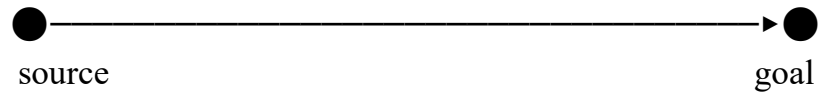

(Fig. 3) Full profiling (dynamic $-\varnothing$ forms) (Hovmark 2007:69) as in (4).

$\begin{array}{llll}\text { (4) Jeg } \quad \text { gik } \quad \text { ud } & \text { på } & \text { marken. } \\ \text { I } & \text { went out[DYN] } & \text { on } & \text { field-ART } \\ \text { 'I went to the field' } & & & \end{array}$

The static form profiles the end point of the path, while the rest of the path may be described as "fictive motion" and constitutes a background for the conceptualization.

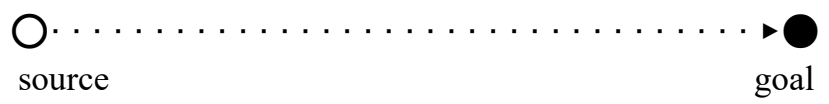

(Fig. 4) Final profiling (static -e forms) (Hovmark 2007:69) as in (5).

(5) Jeg er ind-e i køkkenet

I am inside-STAT in kitchen-ART

'I am in the kitchen'

The procedural form is described by Hovmark as "profiling the path of motion from $\mathrm{p}$ to $\mathrm{q}$ in the path event frame, leaving the starting point (the source) and the end point (the goal) in the unprofiled background" (Hovmark 2013). He also singles out two slightly different uses of the procedural DDA one connected with the non-translocational aspect of the motion event and one focusing on the direction of the motion. The distinction will become more apparent in the later paragraphs of the article.

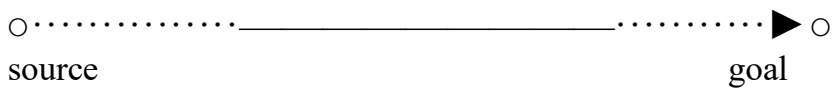

(Fig. 5) Medial profiling (procedural -ad forms) (Hovmark 2007:69) as in (6).

(6) Man burde kigge ind-ad. One should look inside-PROC 'One should look inside'

Another important feature of DDAs is their relation with verbs. Danish language can be classified as an example of a satellite-framed language (Hovmark 2013) which means that DDAs play an important role in forming the meaning of a whole verbal clause in Danish. Peter Harder, Lars Heltoft and Ole Nedergaard Thomsen seem to agree that the relation between DDAs and Danish verbs for the most part corresponds with Talmy's division: 
an adequate description of the Danish system cannot be given if it is assumed that the category "verb" is understood as a monolithic syntactic primitive: Danish syntax habitually splits prototypically verbal meaning between two syntactic constituents, a "host predicate" and a "co-predicate", whose manner of collaboration forms a central part of the organisation of meaning in Danish clauses. Part of this pattern reflects that Danish is what Talmy (1985) has called a "Satellite-framed language": an adverbial particle codes what in other languages forms part of the meaning of the verb. (Harder et al. 1996:160)

In their article, which constitutes an exhaustive characterization of DDAs role within Danish syntax, they focus on a phenomenon named unit accentuation. They define unit accentuation as a situation in which "a main verb is pronounced with weak stress while a constituent associated with the verb receives full stress" (Harder et al. 1996:166) and the definition is followed by an observation that

Absence of full stress from the verb signals that the verb does not serve as clausal predicate on its own, and that the element that receives full stress, i.e. which carries the "unit accentuation", is part of the semantic domain of the clausal predicate. (Harder et al. 1996:167)

All three forms of DDAs (dynamic, procedural and static) seem to fall into this pattern, since they all bear the primary stress:

(7) Jeg ogår 'ud.

I go out[DYN]

'I am going out'

(8) Han oløb 'ud-ad.

$\mathrm{He}$ ran out-PROC

'He ran out'

(9) Han „var 'ud-e.

He was outside-STAT

'He was outside'

This phenomenon is discernible on the expression side of syntax and signals that DDAs take a role of the co-predicate and form a complex clausal predicate with the verb (host-predicate) on the content side. This pattern is far from common for all the European languages and the directional adverbs appear to be an unique form used in Scandinavian languages to convey spatial relations and transitionality. Although both languages are satellite-framed languages, Polish differs from Danish in terms of coding spatial relations and transitionality: 


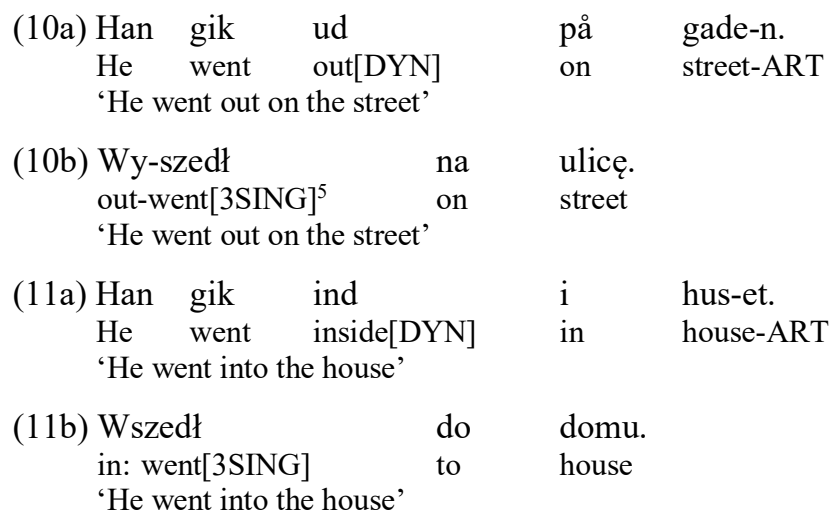

Directionality in Polish is mainly conveyed by prefixes as shown in sentences $10 \mathrm{~b}$ and $11 \mathrm{~b}$. The Polish prefixation system is quite complex and a comprehensive description of it obviously cannot be provided in the present chapter. But the analysis carried out by Smułczyński (2016) shows that in the most cases the Danish dynamic adverb $u d$ is translated into Polish by means of a prefix. Although the wy-prefix is prevalent (40\%), 13 other prefixes have been used which shows that there is no full equivalence between Danish forms and Polish prefixes. It is also worth mentioning that differences in conceptualization of space relations are sometimes revealed by a different choice of the verb that encodes it. As Szubert observes, such differences also occur between Polish and Danish i.e. the Eifel tower ligger (lays) in Danish while it stoi (stands) in Polish (Szubert 2011:330).

\section{THE CONCEPTUALIZATION AND VERBALIZATION OF THE IN-OUT RELATION IN DANISH AND POLISH}

It can be concluded from Henrik Hovmarks Ph.D. dissertation that he singles out two most common image schemas by which the spatial relation inout is embraced: the CONTAINER image schema and the CENTER - PERIPHERY image schema (Hovmark 2007:89). In this chapter I will also employ this division and draw it further. In the part concerning the CONTAINER image schema I will characterize different subcategories of this image schema in regard to the ontological and epistemological status of the objects perceived by its means. The CENTER-PERIPHERY image schema will also be analyzed in order to reveal its linguistic representations in both languages and investigate if it plays an equally important role in Polish and Danish. This should not only reveal the conceptualization of the in-out spatial relation by Danes and Poles,

5 The analysis focuses on verbalization of space relations which is why the Polish examples will not include more detailed morphological distinctions (grammatical gender, case). 
but also establish a foundation for the comparative analysis of how the relation is verbalized in these two respective languages.

\subsection{THE CONTAINER IMAGE SCHEMA}

As George Lakoff and Mark Johnson (Johnson/Lakoff 1980:56-60) point out, the in-out spatial relation is one of the most basic concepts through which we understand other, more complex concepts in the world (along with updown, front-back, near-far etc.). These spatial relations stem from our physical experience and seem to be the most basic and cognitively accessible for humans, which is why we use them to understand and shape the world by means of image schemas. And our experience of the in-out relation is a source to one of the most widespread image schemas through which we humans categorize and understand the world - the CONTAINER image schema. Johnson and Lakoff write:

We experience ourselves as entities, separate from the rest of the world - as CONTAINERS with an inside and an outside. We also experience things external to us as entities - often also as CONTAINERS with insides and outsides. We experience ourselves as being made up of substances - e.g., flesh and bone - and external objects as being made up of various kinds of substances - wood, stone, metal, etc. We experience many things, through sight and touch, as having distinct boundaries, we often project boundaries upon them - conceptualizing them as entities and often as CONTAINERS (for example, forests, clearings, clouds, etc.). (Johnson/Lakoff 1980:58)

Languages have different means to convey the in-out relation: prepositions, suffixes, adverbs etc. The most salient way of conveying the CONTAINER image schema in European languages is the preposition "in". In Danish, especially the static form inde may on surface seem peculiar in that a question arises: Why double up the information about something being inside, since the preposition $i$ already contains this information, and it seems natural to claim that it also presupposes the in-out relation? A comparative analysis may be an adequate way to determine the semantic role of DDAs in that we shall see if it contributes to Danish sentences with additional information in comparison to Polish sentences.

a) We shall start with the most basic type of the CONTAINER image schema, bound to our perception of human's body as a CONTAINER. It is the perception of human's body as a CONTAINER that gives us a foundation for perception of other entities as CONTAINERS. The in-out relation is ever-present in our everyday functioning - we divide the world in the one inside our body and the one outside it (which is reflected in the lexicon of both Polish and Danish i.e. 
in the opposition indre verden vs. ydre verden / świat wewnętrzny vs. świat zewnętrzny ["inside world" vs. "outside world"]). When we talk about the world inside us, we can refer to both physical objects like lungs, stomach and by-passes put inside by a surgeon or entities that need to be embraced by means of a metaphor such as thoughts or feelings, which we perceive as OBJECTS. European languages differ in a way they convey the in-out relation understood by the means of the CONTAINER image schema, but the conceptualization of our body as a CONTAINER can be traced in every of them. Polish and Danish are no exceptions and the conceptualization of the body or certain parts of the body as CONTAINERS is present in both languages in both static and dynamic situations. Let us take a look how the three aforementioned types of profiling of a motion event are verbalized in Polish and Danish. The static in-out relation is present in both languages and we can talk about thoughts being inside our head or perceive ourselves as being outside of our bodies:

(12a) Jeg har mange tanker ind-e i mit hoved. I have many thoughts inside-STAT in my head 'I have many thoughts in my head'

(12b) Mam wiele myśli w głowie. have[1SING] many thoughts in head 'I have many thoughts in my head'

(13a) Jeg føler som om jeg var ud-e af min krop. I feel as if I was outside-STAT of my body

'I feel as if I was outside of my body'

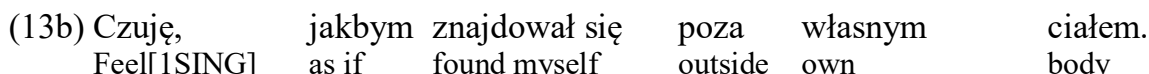
'I feel as if I was outside of my body'

As we can see, there are different ways of coding the in-out relation. In examples (12a) and (12b) we can observe the most common way of conveying the in-relation - prepositions. Sentences in both languages reflect the conceptualization of the head as a CONTAINER by means of equivalent prepositions: $i$ and $w$. What stands out is the directional adverb inde in the Danish sentence. On surface, the use of inde may seem superfluous for a speaker of Polish, because of the preposition $i$ that already indicates that the head is perceived as a CONTAINER. This convergence of what prepositions and directional adverbs refer to will be observed in most cases regarding human body, but, as we shall see in the following paragraphs, the story is more complex and the DDAs may take another relatum than the one denoted by the prepositional phrase. The situation is similar in examples (13a) and (13b) 
where the in-out relation is conveyed by only one element in Polish (poza) and two in Danish (ude, af). The conceptualization of the body as a CONTAINER is also present in dynamic cases as in examples 14-15:

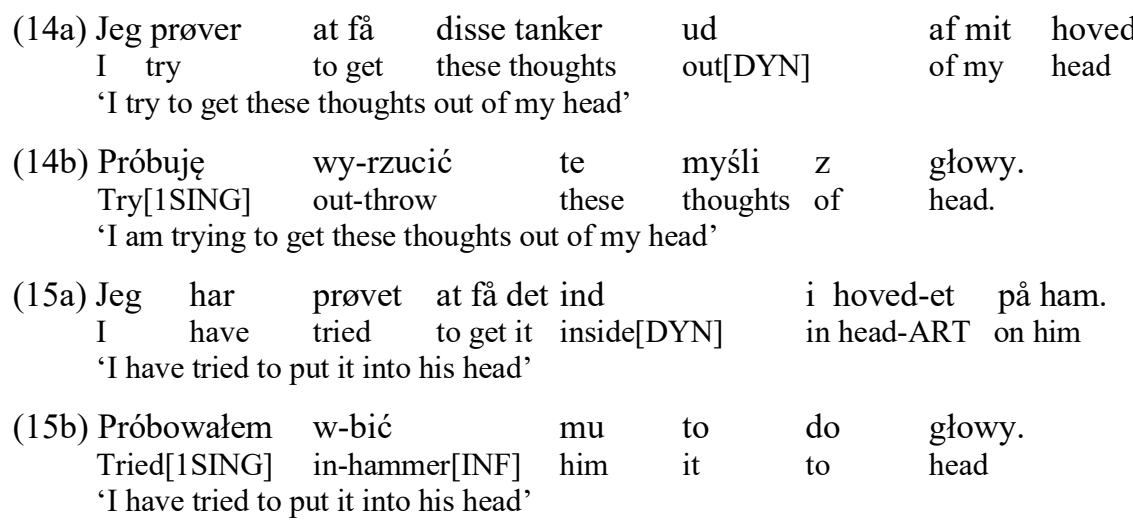

As in the case of the static use, there is a significant difference in verbalization of the in-out relation in Danish and Polish. Both in the case of getting something out of one's head and putting something into it, Danish uses a directional adverb and a preposition ( $u d$ af and ind $i$ ) while in Polish the same conceptualization is conveyed by a prefix and a preposition (wy-, $z$ and $w-, d o$ ). The difference between Polish and Danish in this case is mostly the preposition $d o$ that does not express a state of being inside a CONTAINER (having already crossed the border between the outside and the inside) but rather a process of moving towards the goal. In Danish, the procedural aspect of the in-out relation can be realized by means of a procedural directional adverb as in sentence (16a). In this case, the directional adverb does not require a prepositional phrase or any other complement as in the Polish sentence $16 \mathrm{~b}$. The use of the procedural DDA in situations concerning human body is mostly related to metaphorical uses connected with the opposition soul/mind-outside world. It is also worth mentioning that in this case indad is more common than $u d a d$ :

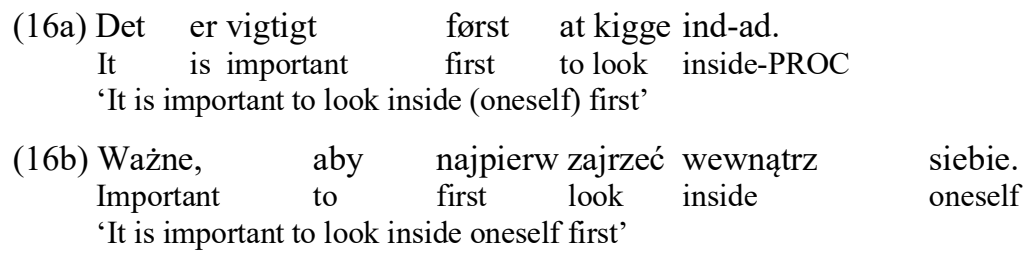

Based on the division carried out by Hovmark, the procedural form indad can be in this and other situations concerning human body said to highlight the 
specific direction rather than convey the non-translocational aspect of the motion.

b) Our perception of the human body as a CONTAINER helps us understand other physically tactile objects with clearly definable borders through the same image schema and, what follows, perceive the in-out relation in these objects. The prototypical objects that we understand as CONTAINERS are objects like buildings, rooms and boxes. By passing the border one goes inside or outside the outlined area and it is now a matter of which kind of activity (or lack of thereof) one does, to decide which of the DDAs to use to profile the whole situation. We can see that also Polish has means to convey the in-out relation in such cases:

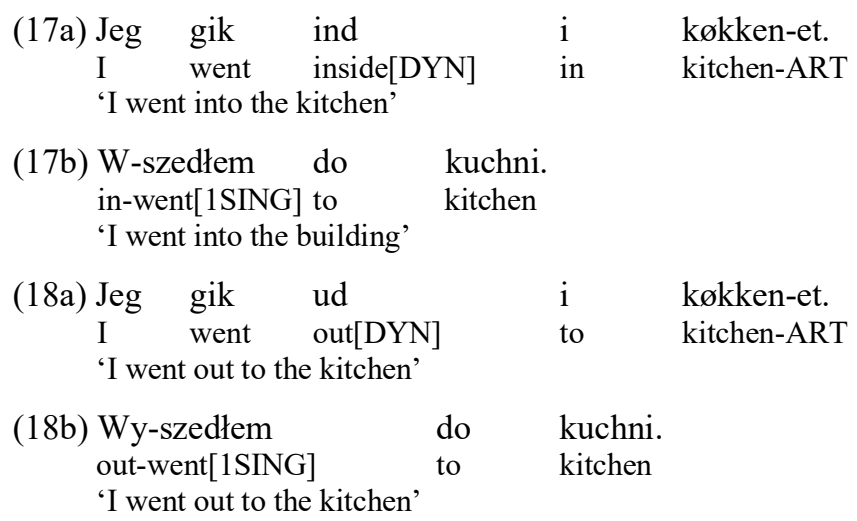

Examples (17a) and (17b) show the same pattern as the examples presented for the previous type of the in-out relation in regard to dynamic situations. There are in both languages two elements that convey the in-out relation, the direction and crossing the border between the outside and the inside of a CONTAINER (DDA+prep. in Danish and prefix+prep. in Polish), and in both languages the in-out relation is bound to a CONTAINER denoted by the prepositional phrase. But the situation in sentence (18a) is different as it contains an on surface contradictory information that the person went both somewhere outside and inside the kitchen at the same time. The conclusion must be that the directional adverb $u d$ and the prepositional phrase in the Danish sentence refer to two different in-out relations, whereas in the Polish example there is only one locative element and there is no doubt what in-out relation it refers to. The Danish sentence (18a) as a whole still refers to a CONTAINER (kitchen) with objectively discernible borders and an inside, but the directional adjective $u d$ in this case conveys another type of the in-out 
relation, which is not connected to the CONTAINER denoted by the prepositional phrase. The same phenomenon can be observed in static situations:

(19a) Jeg var ind-e
I was inside-STAT i

Sentence (20a) proves that DDAs can refer to different in-out relations while the prepositions are always connected to their complement. A DDA may describe the same spatial in-out relation as a preposition but does not have to. It may take a reference point not connected to the CONTAINER denoted by the prepositional phrase, but refer to an in-out relation connected with a different CONTAINER or refer to another type of the in-out relation bound to the CENTER-PERIPHERY image schema. This phenomenon is revealed explicitly mostly in constructions with directional adverbs $u d$, ude and $u d a d$, while the potential of expressing another in-out relation is harder discernible in case of ind, inde and indad. The dynamic use of the directional adverb ud would in many cases not seem strange for a speaker of Polish: in such cases the in-out relation is typically conveyed by the prefix wy- and also regards a CONTAINER different from the one denoted by the prepositional phrase as in sentence (18b). But the lack of difference between sentences (19b) and (20b) shows that this kind of spatial relation is not verbalized in static situations in Polish. So the question here goes beyond a different distribution of content on the expression side of syntax - Polish does not convey some information that in Danish is verbalized on a regular basis, although the conceptualization of the in-out relation in regard to the prototypical CONTAINERS is pretty much the same which is revealed in dynamic uses as in sentence (18b).

Examples of uses of the procedural forms indad and udad in connection to entering or leaving containers such as rooms or buildings are scarce. Many of the examples found in the corpus concerned doors and windows opening inwards as in sentence (21a): 


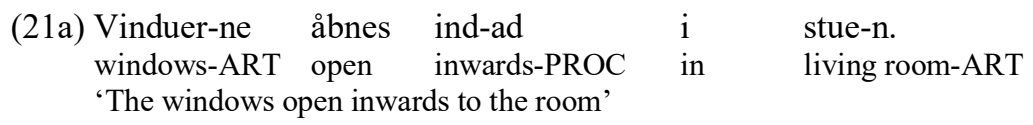

It is also possible, however, to use the procedural DDA while describing the process of i.e. entering a room in order to profile the non-translocational aspect:
(22a) Hun begyndte
at gå ind-ad
She began
to go inward-PROC
'She began to go inside the room again'
i værels-et igen
in room-ART again

Polish offers different means to express the content present in the two sentences above. The directionality is conveyed by lexical means as do wewnatrz in sentence (21b) while the non-transitionality is mostly connected to the aspect of the verb (sentence $22 b$ ):
(21b) Okna
otwierają-się do
wewnątrz.
windows
open-REFL
to inwards
The windows open indwards.
(22b) Zaczęła ponownie w-chodzić do pokoju. Started[3SING] once again in-go to room
'She began to go inside the room again'

c) Entities like forests, fields, cities etc. share from ontological standpoint most features with objects analyzed in the paragraph (b) concerning most prototypical CONTAINERS like buildings and boxes with visible walls on every side - they are part of the objectively existing word, visually and physically accessible for humans. But their borders are not sharply outlined and they are product of human conceptualization. Entities of this type are in both languages conceptualized as CONTAINERS and the in-out relation is in these cases verbalized in accordance to the same pattern as buildings, which means that the DDA may refer to an in-out relation not bound to the in-out relation of the complement of the prepositional phrase, mostly connected to the CENTERPERIPHERY schema as in ude i skoven and ude i marken [outside in the forest, outside in the field]. The conceptualization related to the CENTER-PERIPHERY image schema is not verbalized in static situations in Polish ( $w$ lesie, na polu), but reveals itself in dynamic situations as in wyjechać do lasu [take off to the forest].

Using a procedural DDA is possible in some situations, but it does not occur often together with the entities described in this paragraph and is in most cases connected with the CENTER-PERIPHERY image schema as in indad mod byen, udad mod skoven [inside towards the city, outside towards the forrest]. In such cases the in-out relation is not verbalized in Polish as in w kierunku/do 
miasta and w kierunku/do lasu [in the direction of/to the city, in the direction of/to the forrest].

d) Also feelings and states are understood through the CONTAINER image schema by both Poles and Danes. There can be found many examples proving this claim: we are $i$ form/ $w$ formie [in form], $i$ god sundhed/ $w$ dobrym $z$ drowiu [in good health], we can say something $i$ vrede/ $w$ zlości [in anger] and live $i$ lykke/ w szczęściu [in happiness]. The question is, how the in-out relation is reflected in both languages in regard to this type of CONTAINERS and if DDAs in this situation function in similar ways to the other types of CONTAINERS, analyzed in the preceding paragraphs. Let us focus on the following sentences:

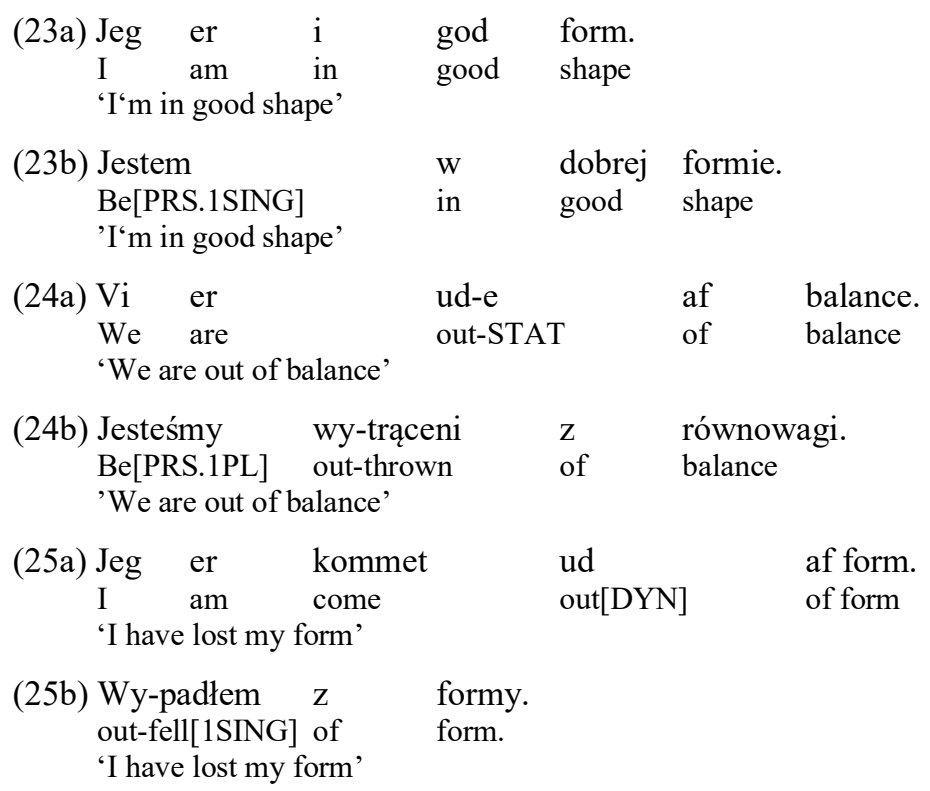

The first pair of sentences describes a static situation of being in good shape. What stands out is the absence of a directional adverb in Danish. The interlocational direction is not expressed unlike the situations concerning physically discernible objects analyzed before. A directional adverb does occur in a sentence describing a transitive action - getting out of form (25a) and the conceptualization of the whole path of motion is also preserved as the ground in the static form (24a). But it can only refer to the in-out relation bound to the complement of the prepositional phrase. That means that in the case of entities such as states and feelings, an in-out relation connected with another reference point other than the one denoted by the complement of the 
prepositional phrase - the entity of this type itself - usually does not occur. It turns out that in the case of entities of this type Polish and Danish, in most cases, convey the same amount of information about the in-out relation, with respect to different expression side elements used in each language. In the Polish sentence $24 \mathrm{~b}$, being outside the state of balance is rooted in the passive participle adjective wytraceni, while prepositions $z$ and af are equivalent in this context. The situation is similar in sentences (25a) and (25b). In contrast to the CONTAINERS described in the other paragraphs, the procedural form is not used with feeling and states.

e) Entities like city districts, regions and especially countries are, likewise forests and fields, non-prototypical CONTAINERS, but in contrast to the CONTAINERS described in paragraph (c) they are highly abstract concepts which borders are primarily evidenced on maps and in documents rather than in the natural world (except situations where borders of countries lay on a river, chain of mountains or other natural barrier). There is no discrepancy in the Danish and Polish conceptualization regarding the borders of these entities. The verbalization of the in-out relation regarding these abstract concepts applies in large part to the pattern embracing more prototypical CONTAINERS: DDAs can also express an in-out relation connected to a different CONTAINER or the CENTER-PERIPHERY image schema, as in the expression ude $i$ Thailand [outside in Thailand], while the reference to the in-out relation is absent in static situations in Polish ( $w$ Tajlandii - in Thailand).

\subsection{THE CENTER-PERIPHERY IMAGE SCHEMA}

The verbalization of the CENTER-PERIPHERY image schema is where the largest differences in Polish and Danish conceptualization of the in-out relation are revealed. But, as Henrik Hovmark points out, it can be in many cases very difficult, if not impossible, to analyze this image schema separately from the CONTAINER image schema, because it based on the relation between a smaller object being inside a bigger object, where the smaller object is conceptualized as the center of the bigger object, which implicates the CONTAINER image schema (Hovmark 2007:100). But there are cases where there is little doubt about the occurrence of the CENTER-PERIPHERY image schema, as in expressions like ude $i$ skoven / i forstcederne / på Nørrebro and $i$ rummet [outside in the forest/suburbs/Nørrebro/space] and in such cases neither of the equivalent Polish expressions contains information about the inout relation bound to the CENTER-PERIPHERY image schema, as in $w$ lesie / na przedmieściach /na Nørrebro / $w$ kosmosie [in the forest/suburbs/Nørrebro/space]. But it is not impossible to comprehend the Danish conceptualization of the in- 
out relation through the CENTER-PERIPHERY image schema, since its general structure can be described as in Fig. 6:

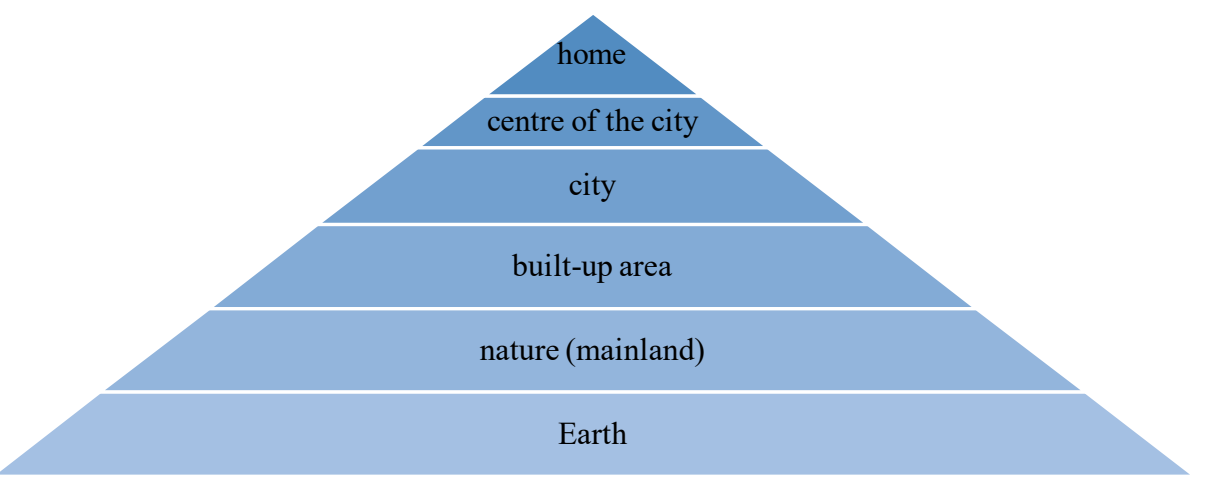

(Fig. 6) The organization of the main reference points in the in - out relation in Danish

My main argument is that there is in most cases a presupposed reference point in expressions where the directional adverb does not refer to the in-out relation denoted by the prepositional phrase. This is most visible in expressions with the static form ude. The longer from home one is, the more general reference point they require to take: the city is $u d e$ in reference to home (ude $i$ byen), the city districts are ude in reference to the centre of the city (ude pa Nørrebro, inde i centrum) and the city in general is more central in reference to other built-up areas around it (ind mod byen, ude i forstcederne). Then nature is perceived as peripheries in reference to built-up areas (ude $i$ naturen, ude $i$ skoven) and within nature mainland is perceived as more central than water reservoirs (ude på havet, ude på søen). Finally planet Earth as a whole is opposed to everything else in space (ude i rummet, ude pa Mars). The hierarchy can be partially reflected in Polish dynamic verbs (wyjechać na wieś, wyptynać $w$ morze), but the CENTER-PERIPHERY image schema in Polish is not expressed on a regular basis (wyjść do lasu refers to leaving a CONTAINER and wyjechać na Nørrebro would seem strange for a Polish speaker). Therefore it is reasonable to conclude, that speakers of Danish perceive more relations through the CENTER-PERIPHERY image schema than Polish speakers.

\section{CONCLUSIONS}

The analysis in the present paper has shown that there are significant differences in conceptualization and verbalization of the in-out relation between Danish and Polish. Two image schemas related to the in-out relation were singled out: a CONTAINER image schema and a CENTER-PERIPHERY image schema. The following analysis has revealed that speakers of both 
languages perceive same entities as CONTAINERS, while the CENTERPERIPHERY image schema is more often verbalized in the Danish language. An additional point was made that in many cases there is a presupposed reference point in Danish expressions with directional adverbs ude conveying the CENTER-PERIPHERY image schema, and that the general structure of the CENTER-PERIPHERY image schema can be described explicitly. The conceptualization of the in-out relation is also conveyed differently on the expression side of grammar in both languages. In Polish the most common form to convey transitionality and direction are constructions prefix + verb, and in Danish these features are expressed by directional adverbs that complement the verb as satellites, while prepositions $i$ and $w$ usually express a state of being inside a CONTAINER in both languages. The situation is, however, more complex in Danish where directional adverbs may refer to being inside a CONTAINER denoted by the prepositional phrase, leaving a CONTAINER different from the one denoted by the prepositional phrase or be connected to the CENTER-PERIPHERY image schema. It would be beneficial to analyze and compare other spatial relations in Polish in Danish in order to get a broader perspective on the conceptualization and verbalization of space in both languages. Especially the Danish adverb hen could be interesting in this context as it does not have any equivalent in Polish and is difficult to understand for Poles.

\section{REFERENCES}

Bjerre, T. (2003). Locative Prepositions and Adverbs in Danish. Nordlyd 31(1), p. 1-12. DOI: http://dx.doi.org/10.7557/12.52.

Hansen, E., Heltoft, L. (2011) Grammatik over det danske sprog. København/Odense: Det Danske Sprog- og Litteraturselskab (DSL), Syddansk Universitetsforlag.

Harder, P. (et al). (1996). Danish directional adverbs Content syntax and complex predicates: A case for host and co-predicates. In: E. Engberg-Pedersen (ed.), Content, Expression and Structure: Studies in Danish Functional Grammar (p. 159-198). Amsterdam: John Benjamins Publishing Company.

Hovmark, H. (2007). Danske retningsadverbier og rumlig orientering. København: Nordisk Forskningsinstitut.

Hovmark, H. (2008). Konventionaliserede forbindelser med danske retningsadverbier leksikografisk repræsentation og funktion. In: Á. Svavarsdóttir, G. Kvaran, G. Ingólfsson, \& J. H. Jónsson (red.), Nordiske studier $i$ leksikografi: Rapport fra konference om leksikografi i Norden Akureyri 22.-26. maj 2007 (Bind 9, s. 227-240). Nordisk forening for leksikografi $\mathrm{Nr} 10$.

Hovmark, H. (2009). Ude og hjemme: - om brugen af retningsadverbier i Jylland og på Øerne. In: $\operatorname{Ord} \&$ Sag 29, p. 5-27.

Hovmark, H. (2013). Danish Directional Adverbs: Ways of Profiling a Motion Event. In: Construal of Spatial Meaning: Windows into Conceptual Space. Oxford University Press. Retrieved from http://www.oxfordscholarship.com/view/10.1093/acprof:oso/9780199641635.001.0001/ acprof-9780199641635-chapter-10 (12 Dec. 2017). 
Johnson, M., Lakoff, G. (1980). Metaphors we live by. Chicago and London: The University of Chicago Press.

Lakoff, G. (2011). Kobiety, ogień i rzeczy niebezpieczne. Co kategorie mówiq nam o umyśle. Kraków: UNIVERSITAS.

Langacker, R. (2005). Wyktady z Gramatyki Kognitywnej. Lublin: Wydawnictwo Uniwersytetu Marii Curie-Skłodowskiej.

Smułczynski M. (2016). Oversættelsesstrategier af retningsadverbiet $u d$ i polske oversættelser af H. C. Andersens Eventyr \& historier. Folia Scandinavica Posnaniensia 20, p. 241-256.

Strzelecka, E. (2003). Svenska partikelverb med "in", "ut", "upp" och "ner". En semantisk studie ur kognitivt perspektiv. Uppsala: Istitutionen för Nordiska Språk vid Uppsala Universitet.

Strzelecka, E. (2014). Att byta perspektiv utan att byta position. Något om perspektiva adverb i svenskan. In: S. Henricson et al. (eds.), Svenskans beskrivning 33 (p. 249-258). Helsingfors: Unigrafia.

Szubert, A. (2011). Noget om positionsverberne ligge, stå og sidde i dansk og polsk. Folia Scandinavica Posnaniensia 12, p. 327-333.

Talmy, L. (2000a). Toward a Cognitive Semantics: Concept Structuring Systems. Cambridge, Mass: A Bradford Book.

Talmy, L. (2000b), Toward a Cognitive Semantics: Typology and Process in Concept Structuring. Cambridge, Mass: A Bradford Book.

\section{Aleksander Kacprzak}

Uniwersytet im. Adama Mickiewicza w Poznaniu

Katedra Skandynawistyki

Collegium Novum

al. Niepodległości 4

61-874 Poznań

Poland

aleksander.kacprzak@amu.edu.pl 